\title{
Radiofrequency radiation from nearby base stations gives high levels in an apartment in Stockholm, Sweden: A case report
}

\author{
LENNART HARDELL $^{1,2,4}$, MICHAEL CARLBERG ${ }^{1,2}$ and LENA K. HEDENDAHL ${ }^{2,3}$ \\ ${ }^{1}$ Department of Oncology, Faculty of Medicine and Health, Örebro University, \\ SE-701 82 Örebro; ${ }^{2}$ The Environment and Cancer Research Foundation, SE-702 17 Örebro; \\ ${ }^{3}$ Independent Environment and Health Research Luleå, SE-972 53 Luleå, Sweden
}

Received November 16, 2017; Accepted February 22, 2018

DOI: $10.3892 / \mathrm{ol} .2018 .8285$

\begin{abstract}
Exposure to radiofrequency (RF) radiation was classified in 2011 as a possible human carcinogen, Group 2B, by the International Agency for Research on Cancer of the World Health Organisation. Evidence of the risk of cancer risk has since strengthened. Exposure is changing due to the rapid development of technology resulting in increased ambient radiation. $\mathrm{RF}$ radiation of sufficient intensity heats tissues, but the energy is insufficient to cause ionization, hence it is called non-ionizing radiation. These non-thermal exposure levels have resulted in biological effects in humans, animals and cells, including an increased cancer risk. In the present study, the levels of RF radiation were measured in an apartment close to two groups of mobile phone base stations on the roof. A total of 74,531 measurements were made corresponding to $\sim 83 \mathrm{~h}$ of recording. The total mean $\mathrm{RF}$ radiation level was $3,811 \mu \mathrm{W} / \mathrm{m}^{2}$ (range 15.2-112,318 $\mu \mathrm{W} / \mathrm{m}^{2}$ ) for the measurement of the whole apartment, including balconies. Particularly high levels were measured on three balconies and 3 of 4 bedrooms. The total mean RF radiation level decreased by $98 \%$ when the measured down-links from the base stations for 2, 3 and $4 \mathrm{G}$ were disregarded. The results are discussed in relation to the detrimental health effects of non-thermal RF radiation. Due to the current high RF radiation, the apartment is not suitable for long-term living, particularly for children who may be more sensitive than adults. For a definitive conclusion regarding the effect of RF radiation from nearby base stations, one option would be to turn them off and repeat the measurements. However,
\end{abstract}

Correspondence to: Professor Lennart Hardell, Department of Oncology, Faculty of Medicine and Health, Örebro University, 1 Fakultetsgatan, SE-701 82 Örebro, Sweden

E-mail: lennart.hardell@environmentandcancer.com

${ }^{4}$ Present address: The Environment and Cancer Research Foundation, Studievägen 35, SE-702 17 Örebro, Sweden

Key words: radiofrequency radiation, microwaves, measurement, exposure, health, cancer the simplest and safest solution would be to turn them off and dismantle them.

\section{Introduction}

The use of wireless digital technology has grown rapidly during the last couple of decades. While in use, mobile and cordless phones emit radiofrequency $(\mathrm{RF})$ radiation. The brain is the main target of exposure to RF radiation with handheld wireless phones (mobile and cordless) $(1,2)$. An increased risk for brain tumors has been of concern for a long time. In May 2011, RF radiation in the range 30-300 GHz could be categorized in Group 2B, i.e., a 'possible' human carcinogen, by the International Agency for Research on Cancer (IARC) of WHO $(3,4)$. The decision was based mainly on case-control human studies on the use of wireless phones by the Hardell group in Sweden (mobile and cordless phones; DECT) and the IARC Interphone study (mobile phones), which showed an increased risk for brain and head tumours, i.e., glioma and acoustic neuroma (3-6), which has since been confirmed (7-10), resulting in a recommendation to upgrade IARC's 2011 classification of RF radiation to Group 1, a human carcinogen. This conclusion was published in our up-dated review in 2013 (11) using the so-called Hill viewpoints on the association or causation put forward at the height of the tobacco and lung cancer controversy (12).

Due to the increasing use of the wireless technology, environmental exposure to RF radiation has been increasing, but there has been no systematic study of ambient exposure. We have measured RF radiation at Stockholm Central Station (13) and the Stockholm Old Town in Sweden (14). The results generally exceeded the levels known to have adverse biological effects. By contrast, low levels were measured at certain places in the WHO building in Geneva (15).

We have measured RF radiation in an apartment with a central location at Östermalm in Stockholm. The apartment is located on the 6th floor, with a tower including a bedroom on the first floor of the tower (7th floor) and a conference room on the second and highest floor (8th) of the tower, at the same level as the roof of the building. The measurements did not involve any human subjects, and therefore no ethical permission was needed. We also discuss laboratory studies on RF-radiation and biological effects relative to the levels of RF in question. Of particular interest are the non-thermal levels of RF radiation and 
biological effects. For comparison, radiation was also measured in another apartment located on the 3rd floor in a high building of 9 floors at Gärdet in central part of Stockholm.

\section{Materials and methods}

EME-Spy 200 exposimeter. To measure RF radiation, a calibrated exposimeter EME-Spy 200 (Satimo, MVG Industries, Brest, France) was used. The instrument measures 20 predefined frequency bands (Table I), which cover the frequencies of most public RF radiation emitting devices now in use in Sweden. These frequencies are from 87 to $5,850 \mathrm{MHz}$. For frequency modulation (FM), TV3, TETRA, TV4\&5, Wi-Fi $2.4 \mathrm{GHz}$ and Wi-Fi $5 \mathrm{GHz}$, the lower detection limit is $0.01 \mathrm{~V} / \mathrm{m}\left(0.27 \mu \mathrm{W} / \mathrm{m}^{2}\right)$. For all other bands, the lower detection limit is $0.005 \mathrm{~V} / \mathrm{m}\left(0.066 \mu \mathrm{W} / \mathrm{m}^{2}\right)$. For all bands, the upper detection limit is $6 \mathrm{~V} / \mathrm{m}\left(95,544 \mu \mathrm{W} / \mathrm{m}^{2}\right)$. Samples were taken every 4 th second.

The exposimeter measures different telecommunications protocols: FM radio broadcasting; TV broadcasting; TETRA emergency services (police and rescue); GSM second generation mobile communications, 2G; UMTS third generation mobile communications, 3G; long-term evolution (LTE) fourth generation mobile communications standard, $4 \mathrm{G}$; digital European cordless telecommunications (DECT) cordless telephone systems standard; Wi-Fi $2.4 \mathrm{GHz}$ and $5 \mathrm{GHz}$ wireless local area network protocol; worldwide interoperability for microwave access (WiMAX) wireless communication standard for high-speed voice, data and Internet.

EME-Spy 200 has a 3-axis antenna to capture RF radiation from every direction. The unit reports the exposure after statistical processing, since each value is a sampling outcome of many readings after statistical analysis, including minimum, mean, median and maximum values.

Study design. Measurements were taken on June 5, 6, and August 21, 22, 30, 31, 2017. Some measurements were made during the night to assess variation of RF exposure from daytime readings. While walking through all the rooms and balconies, the effect of body shielding was minimized by the exposimeter being held about $0.4 \mathrm{~m}$ in front of the investigator. More extended measurements were then taken in places judged to be of interest-bedrooms and the living room. The exposimeter was placed where people tend to occupy, e.g., corresponding to the upper part of the body, including the head of a bed. Three of the five balconies were located close to the 2 groups of base stations located on the roofs. The closest base stations were only $6 \mathrm{~m}$ from the balcony outside the tower.

Measurements in another apartment for comparison at Gärdet, Stockholm were taken on October 27-29 and November 6, 2017. This was a smaller apartment with a balcony and no visible surrounding base stations. A group of base stations are located at the top of another 9 floor building, but in the opposite direction to this apartment.

Statistical methods. Means, medians, minimum, and maximum values in $\mu \mathrm{W} / \mathrm{m}^{2}$ were calculated for all measured frequency bands, and box plots and bar graphs were constructed to illustrate the distribution of total exposure for all measurement rounds. Values at the lower detection limit were treated as zero exposure. Total exposure was calculated as the sum of all measured frequency bands. Stata/SE 12.1 (Stata/SE 12.1 for Windows; StataCorp., College Station, TX, USA) was used for all calculations.

\section{Results}

Whole apartment. The total of measurements made at the apartment in Östermalm was 74,531 readings ( $83 \mathrm{~h}$ of recording). The daily data were consistent; therefore, totals are presented for the whole apartment including different locations. Some places of interest will be discussed in greater detail. The results are given as numbers of readings (measurements), and as mean, median, minimum and maximum values in $\mu \mathrm{W} / \mathrm{m}^{2}$.

Table II shows mean level $3,810.8 \mu \mathrm{W} / \mathrm{m}^{2}$ for the total measurement of the whole apartment, including balconies, a high maximum level of $112,318 \mu \mathrm{W} / \mathrm{m}^{2}$ being recorded. Over $55 \%$ of the mean level was caused by the $4 \mathrm{G}$ down link from base stations (LTE 800 and LTE 2600). The $3 \mathrm{G}$ down link (GSM+UMTS 900 and UMTS 2100) yielded $>40 \%$ of the total mean exposure. About $96 \%$ of the total mean value was caused by the $3 \mathrm{G}$ and $4 \mathrm{G}$ down links, with the $2 \mathrm{G}$ down link accounting for only $2 \%$ (GSM 1800). The results were calculated excluding all $\mathrm{RF}$ radiation from base stations, which gave a mean level $78.8 \mu \mathrm{W} / \mathrm{m}^{2}$ and maximum $4,616.2 \mu \mathrm{W} / \mathrm{m}^{2}$, Table II. Thus $3,732.0 \mu \mathrm{W} / \mathrm{m}^{2}, 97.9 \%$ of the mean RF radiation was caused by down link from the $2 \mathrm{G}, 3 \mathrm{G}$ and $4 \mathrm{G}$ base stations.

The measurements in the apartment, excluding the 5 balconies, were based on 64,070 readings ( $71 \mathrm{~h}$ of measurements). The mean level was $1,766 \mu \mathrm{W} / \mathrm{m}^{2}$; median $1,051 \mu \mathrm{W} / \mathrm{m}^{2}$ (range $\min 15.2 \mu \mathrm{W} / \mathrm{m}^{2}, \max 50,431.0 \mu \mathrm{W} / \mathrm{m}^{2}$; data not shown). These results nevertheless represent high levels of RF radiation.

Table III gives the levels for different locations within the apartment, and Table IV shows the results where the contribution from base stations is excluded at each location; thereby substantially lower values were generally obtained.

Balconies. The highest results were inevitably found on the balconies, especially the 3 facing at short distance the visible base stations. The highest mean value $\left(24,885.9 \mu \mathrm{W} / \mathrm{m}^{2}\right)$ was measured on the balcony outside the living room (Table V), at which the highest maximum exposure was found $\left(112,317.7 \mu \mathrm{W} / \mathrm{m}^{2}\right)$. The results were based on 5,251 entries corresponding to $\sim 6 \mathrm{~h}$ of measurements. If the down link of RF radiation from the base stations was disregarded, the total mean on that balcony fell to $229.6 \mu \mathrm{W} / \mathrm{m}^{2}(\sim 0.9 \%$ of the total; Table V). The balconies outside the boy's bedroom and outside the tower gave similar results with high RF radiation from nearby base stations (Tables III and IV). Thus the mean RF radiation value outside the boy's bedroom was reduced from $6,803.3 \mu \mathrm{W} / \mathrm{m}^{2}$ to $90.2 \mu \mathrm{W} / \mathrm{m}^{2}$ when disregarding down links from base stations. For the balcony outside the tower, the RF radiation fell from $8,989.4$ to $331.2 \mu \mathrm{W} / \mathrm{m}^{2}$ excluding down links.

Bedrooms. Most of the time is usually spent in bedroom. The master bedroom showed lower RF radiation values compared with the other bedrooms, mean 569.7, and $32.4 \mu \mathrm{W} / \mathrm{m}^{2}$ excluding down links (Tables III and IV). Especially high levels were recorded in the two children's bedrooms and the 
Table I. Predefined measurement frequency bands of EME-Spy 200 Exposimeter. Frequency ranges.

\begin{tabular}{lcc}
\hline & $\begin{array}{c}\text { Frequency } \\
\text { Min } \\
\text { Frequency band }\end{array}$ & $\begin{array}{c}\text { Frequency } \\
\text { Max } \\
(\mathrm{MHz})\end{array}$ \\
\hline FM & 87 & 107 \\
TV3 & 174 & 223 \\
TETRA I & 380 & 400 \\
TETRA II & 410 & 430 \\
TETRA III & 450 & 470 \\
TV4\&5 & 470 & 770 \\
LTE 800, 4G (DL) & 791 & 821 \\
LTE 800, 4G (UL) & 832 & 862 \\
GSM 900 + UMTS 900, 3G (UL) & 880 & 915 \\
GSM 900 + UMTS 900, 3G (DL) & 925 & 960 \\
GSM 1800, 2G (UL) & 1,710 & 1,785 \\
GSM 1800, 2G (DL) & 1,805 & 1,880 \\
DECT & 1,880 & 1,900 \\
UMTS 2100, 3G (UL) & 1,920 & 1,980 \\
UMTS 2100, 3G (DL) & 2,110 & 2,170 \\
Wi-Fi, 2GHz & 2,400 & $2,483.5$ \\
LTE 2600, 4G (UL) & 2,500 & 2,570 \\
LTE 2600, 4G (DL) & 2,620 & 2,690 \\
WiMax & 3,300 & 3,900 \\
Wi-Fi 5GHz & 5,150 & 5,850 \\
\hline
\end{tabular}

FM, frequency modulation; TV, television; LTE, long-term evolution; DL, downlink (transmission from base station to mobile phone); UL, uplink (transmission from mobile phone to base station); GSM, global system for mobile communications; UMTS, universal mobile telecommunications system; DECT, digital European cordless telecommunications; WiMAX, worldwide interoperability for microwave access.

one located in the tower (Tables VI-VIII). In the girl's bedroom, the mean level was $2,531.0 \mu \mathrm{W} / \mathrm{m}^{2}$ (Table $\mathrm{VI}$ ), whereas in the boy's bedroom it was $1,471.1 \mu \mathrm{W} / \mathrm{m}^{2}$ (Table VII). The highest RF radiation level in the bedrooms was recorded in the tower bedroom, mean value $5,954.3 \mu \mathrm{W} / \mathrm{m}^{2}$, Table VIII. Most of the RF radiation came from down links from the base stations, whereas excluding them gave a mean level in the girl's bedroom of $34.1 \mu \mathrm{W} / \mathrm{m}^{2}, 13.4 \mu \mathrm{W} / \mathrm{m}^{2}$ in the boy's bedroom, and $205.4 \mu \mathrm{W} / \mathrm{m}^{2}$ in the tower bedroom. Thus, RF radiation in the children's bedrooms was reduced $~ 99 \%$, and by $97 \%$ in the tower bedroom by excluding down links from the base stations.

Fig. 1 shows box plots of median levels for all 18 measured areas, with the results in increasing median levels of RF radiation. The bottom and top of the boxes represent first and third quartiles of the levels, with outliers shown as points. Without doubt the balconies had the highest levels, especially the 3 visibly near the surrounding base stations. Fig. 2 shows a bar graph of the mean levels.

There was little variation of the levels in the day and night. Some fall in the measurements were noted from midnight until
Table II. Levels of RF-radiation in total based on 74,531 entries for 6 different tours (Östermalm, Stockholm).

\begin{tabular}{|c|c|c|c|c|}
\hline Variable & Mean & Median & Min & $\operatorname{Max}$ \\
\hline FM & 38.3 & 3.4 & 0.0 & $3,441.2$ \\
\hline TV3 & 4.7 & 0.0 & 0.0 & 308.4 \\
\hline TETRA I & 1.2 & 0.0 & 0.0 & 229.3 \\
\hline TETRA II & 0.2 & 0.0 & 0.0 & 33.9 \\
\hline TETRA III & 0.1 & 0.0 & 0.0 & 26.5 \\
\hline TV4\&5 & 3.0 & 0.0 & 0.0 & $2,206.2$ \\
\hline LTE 800 (DL) & 977.5 & 299.5 & 1.1 & $52,526.5$ \\
\hline LTE 800 (UL) & 0.0 & 0.0 & 0.0 & 2.5 \\
\hline $\begin{array}{l}\text { GSM + UMTS } \\
900 \text { (UL) }\end{array}$ & 0.0 & 0.0 & 0.0 & 4.5 \\
\hline $\begin{array}{l}\text { GSM + UMTS } \\
900(\mathrm{DL})\end{array}$ & $1,236.2$ & 459.0 & 2.5 & $44,241.5$ \\
\hline GSM 1800 (UL) & 0.0 & 0.0 & 0.0 & 7.5 \\
\hline GSM 1800 (DL) & 78.9 & 17.8 & 0.3 & $8,442.1$ \\
\hline DECT & 27.3 & 5.1 & 0.0 & $4,614.8$ \\
\hline UMTS 2100 (UL) & 0.0 & 0.0 & 0.0 & 5.6 \\
\hline UMTS 2100 (DL) & 301.8 & 92.8 & 0.2 & $18,445.0$ \\
\hline WIFI $2 \mathrm{G}$ & 0.0 & 0.0 & 0.0 & 203.5 \\
\hline LTE 2600 (UL) & 3.9 & 0.0 & 0.0 & 904.7 \\
\hline LTE 2600 (DL) & $1,137.5$ & 70.5 & 0.5 & $95,522.5$ \\
\hline WIMax & 0.0 & 0.0 & 0.0 & 2.7 \\
\hline WIFI 5G & 0.1 & 0.0 & 0.0 & 105.0 \\
\hline Total & $3,810.8$ & $1,312.9$ & 15.2 & $112,317.7$ \\
\hline $\begin{array}{l}\text { Total excluding } \\
\text { down link }\end{array}$ & 78.8 & 27.0 & 0.0 & $4,616.2$ \\
\hline
\end{tabular}

Data is based on 74,531 entries for 6 different tours, June 5, 6 and August 21, 22, 30, 31, 2017 (apartment at Östermalm, Stockholm). Analysis of all data $\left(\mu \mathrm{W} / \mathrm{m}^{2}\right)$ treating values at detection limit as 0 . Frequency bands are given. FM, frequency modulation; TV, television; LTE, long-term evolution; DL, downlink (transmission from base station to mobile phone); UL, uplink (transmission from mobile phone to base station); GSM, global system for mobile communications; UMTS, universal mobile telecommunications system; DECT, digital European cordless telecommunications; WiMAX, worldwide interoperability for microwave access.

early morning in the boy's bedroom (Fig. 3), but there was still a high level of RF radiation.

Apartment at Gärdet for comparison. Data for the apartment at Gärdet, Stockholm, based on 36,799 entries corresponding to $\sim 40$ h of measurements are given in (Table IX). The highest $\mathrm{RF}$ radiation was measured on the balcony, but the total mean remained low, $15.6 \mu \mathrm{W} / \mathrm{m}^{2}\left(\min 2.2, \max 195.1 \mu \mathrm{W} / \mathrm{m}^{2}\right)$. About $50 \%$ of the RF radiation was caused by the GSM + UMTS 900 (3G) down link.

\section{Discussion}

The results were based on a large sample of measurements in the apartment at Östermalm, Stockholm representing about $83 \mathrm{~h}$ 
Table III. Levels of RF-radiation in total for different locations in the apartment (Östermalm, Stockholm).

\begin{tabular}{|c|c|c|c|c|c|}
\hline \multirow[b]{2}{*}{ Location } & \multicolumn{5}{|c|}{ Total } \\
\hline & No. & Mean & Median & Min & Max \\
\hline 1. Balcony outside kitchen ${ }^{a}$ & 166 & $1,083.2$ & 895.6 & 226.5 & $5,026.6$ \\
\hline 2. Kitchen & 1,973 & 256.4 & 194.0 & 70.4 & $2,091.7$ \\
\hline 3. Dining room & 4,272 & $1,480.6$ & 854.1 & 93.6 & $12,068.7$ \\
\hline 4. Master bedroom & 12,920 & 569.7 & 370.5 & 36.1 & $6,280.8$ \\
\hline 5. Balcony outside bathroom ${ }^{a}$ & 506 & $1,912.8$ & $1,684.4$ & 31.8 & $6,475.8$ \\
\hline 6. Living room & 4,415 & 321.7 & 236.1 & 15.2 & $8,782.6$ \\
\hline 7. Balcony outside living room & 5,251 & $24,885.9$ & $22,256.1$ & 72.0 & $112,317.7$ \\
\hline 8. Main hall ${ }^{\mathrm{a}}$ & 59 & 185.2 & 154.2 & 59.6 & 512.7 \\
\hline 9. Workroom close to kitchen ${ }^{\mathrm{a}}$ & 599 & 266.9 & 235.3 & 123.6 & $2,135.6$ \\
\hline 10. Workroom close to laundry & 3,899 & $1,310.1$ & $1,044.6$ & 266.0 & $7,999.8$ \\
\hline 11. Laundry ${ }^{\mathrm{a}}$ & 388 & $1,561.6$ & $1,416.0$ & 193.2 & $7,843.2$ \\
\hline 12. Girl's bedroom & 11,440 & $2,531.0$ & $2,270.5$ & 79.1 & $11,802.6$ \\
\hline 13. Boy's bedroom & 14,161 & $1,471.1$ & $1,122.3$ & 58.5 & $13,739.1$ \\
\hline 14. Balcony outside boy's room ${ }^{\mathrm{a}}$ & 777 & $6,803.3$ & $3,254.9$ & 65.3 & $107,992.5$ \\
\hline 15. Hall outside elevator ${ }^{\mathrm{a}}$ & 90 & 251.3 & 197.6 & 24.3 & $1,590.1$ \\
\hline 16. Bedroom in tower & 6,797 & $5,954.3$ & $4,503.5$ & 96.8 & $50,431.0$ \\
\hline 17. Conference room in tower & 3,057 & 432.5 & 229.3 & 89.9 & $12,840.7$ \\
\hline 18. Balcony outside tower & 3,761 & $8,989.4$ & $7,848.8$ & 43.5 & $56,191.3$ \\
\hline Whole apartment & 74,531 & $3,810.8$ & $1,312.9$ & 15.2 & $112,317.7$ \\
\hline
\end{tabular}

aOnly measured June 2017. Levels of RF-radiation in total for different locations in the apartment (Östermalm, Stockholm) based on measurements in June 5, 6 and August 21,22, 30,31, 2017. Analysis of all data $\left(\mu \mathrm{W} / \mathrm{m}^{2}\right)$ treating values at detection limit as 0 . Numbers of entries are given for the different locations.

of recording. High levels of RF radiation were clearly measured throughout the apartment, but especially on the 3 balconies. Most of the RF radiation came from the outside base stations. The total mean level in the apartment fell from $3,810.8$ to $78.8 \mu \mathrm{W} / \mathrm{m}^{2}$, a reduction of $\sim 98 \%$ occurring if the down links from base stations were excluded.

Table II shows that $\mathrm{TV}$ and radio communications contributed only to a minor extent. The contribution was more pronounced at the balcony outside the kitchen in the direction of the transmitting tower (mean level of $276.4 \mu \mathrm{W} / \mathrm{m}^{2}$ for all TV and radio communications; data not in the Table). Most of the $\mathrm{RF}$ radiation in the tower bedroom was also caused by radio/TV towers when down links from base stations were excluded (see Table VIII). A minor contribution was from the DECT frequency (Table II). The source of radiation was probably from a neighboring apartment, since no DECT phone was used in the present apartment.

The highest RF radiation levels were measured on the balconies (Figs. 1 and 2 give median and mean values). Fig. 4 shows the group of base stations located only $12 \mathrm{~m}$ from the balcony outside the living room. It is questionable whether these balconies are suitable for any longer stay due to the high radiation; the balcony outside the living room (with mean level $24,885.9 \mu \mathrm{W} / \mathrm{m}^{2}$, median $22,256.1 \mu \mathrm{W} / \mathrm{m}^{2}$, and maximum level $\left.112,317.7 \mu \mathrm{W} / \mathrm{m}^{2}\right)$ gave the highest of all recorded measurements (Table V). Regarding all 5 balconies, the results were based on 10,461 readings ( $>11 \mathrm{~h}$ of measurements). The mean level was $16,338.7 \mu \mathrm{W} / \mathrm{m}^{2}$, with a median of $13,775 \mu \mathrm{W} / \mathrm{m}^{2}$ (range $\min 31.8, \max 112,318 \mu \mathrm{W} / \mathrm{m}^{2}$ ). Usually balconies in Sweden are used only briefly due to the climate, but nevertheless these results far exceed levels known to be detrimental to health from $\mathrm{RF}$ radiation.

The use of balconies with decent views can be used for pleasure, a part of comfortable living, but most of the day and night is spent in the apartment. Thus, the level of RF radiation inside is of more concern, especially for a family with children. Notably there was high RF radiation in the bedrooms occupied by children, as also in the tower bedroom. There was little variation with time, although the level declining during night (Fig. 3) still exceeded what is known to give non-thermal biological effects from long-term RF radiation. In the boy's bedroom there seemed to be 2 steps in the reduction of radiation during night, one from approximately 7:00 p.m. and another from midnight, indicating less use of wireless communication after business hours and during late leisure time.

Interestingly measurements recorded in another centrally located apartment in Gärdet were considerably lower in RF radiation. Thus, the mean level was only $0.4 \%$ of that found in the apartment at Östermalm. The mean RF radiation on the balcony in Gärdet was much lower; only $0.3 \%$ of that on the balcony outside the living room in Östermalm. These results show extreme variation of RF radiation in 2 residential apartments in Stockholm. 
Table IV. Levels of RF-radiation in total excluding down links in the apartment (Östermalm, Stockholm).

Total excluding down links

\begin{tabular}{|c|c|c|c|c|c|}
\hline \multirow[b]{2}{*}{ Location } & \\
\hline & No. & Mean & Median & Min & $\operatorname{Max}$ \\
\hline 1. Balcony outside kitchen ${ }^{\mathrm{a}}$ & 166 & 288.2 & 310.3 & 68.1 & 565.1 \\
\hline 2. Kitchen & 1,973 & 87.4 & 44.5 & 15.0 & 440.7 \\
\hline 3. Dining room & 4,272 & 70.8 & 68.4 & 20.0 & 461.0 \\
\hline 4. Master bedroom & 12,920 & 32.4 & 22.5 & 4.8 & 606.5 \\
\hline 5. Balcony outside bathroom ${ }^{\mathrm{a}}$ & 506 & 77.3 & 56.8 & 5.8 & 687.1 \\
\hline 6. Living room & 4,415 & 26.8 & 25.5 & 2.0 & 383.8 \\
\hline 7. Balcony outside living room & 5,251 & 229.6 & 146.5 & 0.0 & $4,155.6$ \\
\hline 8. Main hall ${ }^{\mathrm{a}}$ & 59 & 41.3 & 28.4 & 5.7 & 282.9 \\
\hline 9. Workroom close to kitchen ${ }^{a}$ & 599 & 40.6 & 31.5 & 14.0 & $2,004.3$ \\
\hline 10. Workroom close to laundry & 3,899 & 25.3 & 19.4 & 6.7 & $2,199.0$ \\
\hline 11. Laundry ${ }^{\mathrm{a}}$ & 388 & 38.4 & 26.0 & 3.2 & 343.6 \\
\hline 12. Girl's bedroom & 11,440 & 34.1 & 23.1 & 7.2 & $1,069.8$ \\
\hline 13. Boy's bedroom & 14,161 & 13.4 & 6.8 & 0.0 & 427.8 \\
\hline 14. Balcony outside boy's room ${ }^{a}$ & 777 & 90.2 & 52.6 & 0.0 & $4,616.2$ \\
\hline 15. Hall outside elevator ${ }^{\mathrm{a}}$ & 90 & 28.3 & 22.0 & 0.2 & 157.8 \\
\hline 16. Bedroom in tower & 6,797 & 205.4 & 158.4 & 13.5 & $3,457.8$ \\
\hline 17. Conference room in tower & 3,057 & 44.5 & 36.7 & 9.4 & 743.4 \\
\hline 18. Balcony outside tower & 3,761 & 331.2 & 363.8 & 3.8 & $1,618.4$ \\
\hline Whole apartment & 74,531 & 78.8 & 27.0 & 0.0 & $4,616.2$ \\
\hline
\end{tabular}

${ }^{a}$ Only measured June 2017. Levels of RF-radiation in total excluding down links for different locations in the apartment (Östermalm, Stockholm) based on measurements in June 5, 6 and August 21, 22, 30,31, 2017. Analysis of all data $\left(\mu \mathrm{W} / \mathrm{m}^{2}\right)$ treating values at detection limit as 0 . Numbers of entries are given for the different locations. Down links from base stations are excluded.

The guideline for RF radiation in Sweden is set on the false assumption that adverse health effects are caused only by heating. However, human, animal and cell studies show biological effects at non-thermal exposure levels that are often exceeded during the life-time of most people, especially as shown from the measurements in the Östermalm apartment during this study. Exposure to RF radiation levels in the current study may clearly increase the risk for adverse health effects in the long run, since levels giving non-thermal biological effects are generally exceeded. Our findings will now be related to other measurements of RF radiation exposure, guidelines and studies regarding health issues.

Levels of RF radiation have increased considerably in recent years, both outdoor and indoor, due to new telecommunication technologies and protocols. In 2013, Estenberg and Augustsson (16) measured outdoor exposure with a car-based measuring system in Sweden. The median power-density for RF fields between $30 \mathrm{MHz}$ and $3 \mathrm{GHz}$ was measured in rural areas at $16 \mu \mathrm{W} / \mathrm{m}^{2}$, urban areas $270 \mu \mathrm{W} / \mathrm{m}^{2}$, and city areas $2,400 \mu \mathrm{W} / \mathrm{m}^{2}$. The EME-Spy 200 exposimeter was used to measure 2 areas of high exposure to RF radiation in Stockholm. At the Central Railway Station, the mean total RF radiation level varied between 2,817 and $4,891 \mu \mathrm{W} / \mathrm{m}^{2}$ (min 5.8, $\max 155,263 \mu \mathrm{W} / \mathrm{m}^{2}$ ) when walking around (13). The total $\mathrm{RF}$ radiation in the Stockholm Old Town varied between a mean of $404 \mu \mathrm{W} / \mathrm{m}^{2}\left(\min 20.4, \max 4,088 \mu \mathrm{W} / \mathrm{m}^{2}\right)$ on the streets around the Supreme Court, $756 \mu \mathrm{W} / \mathrm{m}^{2}$ (min 0.3, max
$50,967 \mu \mathrm{W} / \mathrm{m}^{2}$ ) around the Royal Castle, and 24,277 $\mu \mathrm{W} / \mathrm{m}^{2}$ $\left(\min 257, \max 173,302 \mu \mathrm{W} / \mathrm{m}^{2}\right)$ at Järntorget, which is a popular square with shops and outdoor restaurants (14).

Calvente et al in Spain (17) measured outside the homes of 123 boys aged 10 years. For all houses, the root mean-square of power density $\left(\mathrm{S}_{\mathrm{RMS}}\right)$ was $286 \mu \mathrm{W} / \mathrm{m}^{2}$ and the maximum power density $\left(\mathrm{S}_{\mathrm{RMS}}\right)$ was $2,760 \mu \mathrm{W} / \mathrm{m}^{2}$ for frequencies between $100 \mathrm{kHz}$ and $6 \mathrm{GHz}$. The range between highest and lowest measured mean was large, ranging from 5.5 to $11,560 \mu \mathrm{W} / \mathrm{m}^{2}$. The 10 -year old boys with higher exposure of RF radiation in their immediate surroundings of their dwellings showed statistically significant lower scores in expression and comprehension, and higher behavioral and emotional problems, including anxiety and depressed behavior in different tests.

Usually much lower RF radiation exposure inside homes is measured since the walls can act as a shield against RF radiation. Frei et al (18) got 166 volunteers measure the frequencies 88-2,500 MHz with a body-born exposimeter (EME-Spy 120) in Switzerland. In the homes, the total mean value was $100 \mu \mathrm{W} / \mathrm{m}^{2}$, and total median $44 \mu \mathrm{W} / \mathrm{m}^{2}$. The maximum level in the homes was $1,212 \mu \mathrm{W} / \mathrm{m}^{2}$.

Roser et al (19) got 90 adolescents to carry a body-born exposimeter (Expo-RF) for 3 consecutive days to measure frequencies from 620 to $2,450 \mathrm{MHz}$. The total mean for these measurements was $63.2 \mu \mathrm{W} / \mathrm{m}^{2}$, and the total mean measured in the homes was $32.1 \mu \mathrm{W} / \mathrm{m}^{2}$. 
Table V. Levels of RF-radiation at the balcony outside the living room (Östermalm, Stockholm).

\begin{tabular}{|c|c|c|c|c|c|c|c|c|c|}
\hline Variable & Mean & Median & Min & Max & Variable & Mean & Median & Min & $\operatorname{Max}$ \\
\hline FM & 6.3 & 1.2 & 0.0 & $2,139.0$ & $\mathrm{FM}$ & 1.2 & 0.5 & 0.0 & $1,056.1$ \\
\hline TV3 & 0.7 & 0.0 & 0.0 & 66.2 & TV3 & 0.1 & 0.0 & 0.0 & 28.7 \\
\hline TETRA I & 0.0 & 0.0 & 0.0 & 3.4 & TETRA I & 0.0 & 0.0 & 0.0 & 0.0 \\
\hline TETRA II & 0.0 & 0.0 & 0.0 & 0.9 & TETRA II & 0.0 & 0.0 & 0.0 & 1.0 \\
\hline TETRA III & 0.0 & 0.0 & 0.0 & 2.7 & TETRA III & 0.0 & 0.0 & 0.0 & 1.4 \\
\hline TV4\&5 & 9.3 & 0.0 & 0.0 & 828.9 & TV4\&5 & 0.2 & 0.0 & 0.0 & 44.8 \\
\hline LTE 800 (DL) & $1,280.2$ & 706.2 & 4.9 & $17,533.3$ & LTE 800 (DL) & 327.0 & 156.6 & 12.6 & $3,980.4$ \\
\hline LTE 800 (UL) & 0.0 & 0.0 & 0.0 & 0.2 & LTE 800 (UL) & 0.0 & 0.0 & 0.0 & 0.3 \\
\hline $\begin{array}{l}\text { GSM + UMTS } \\
900 \text { (UL) }\end{array}$ & 0.0 & 0.0 & 0.0 & 0.3 & $\begin{array}{l}\text { GSM + UMTS } \\
900 \text { (UL) }\end{array}$ & 0.0 & 0.0 & 0.0 & 0.1 \\
\hline $\begin{array}{l}\text { GSM + UMTS } \\
900 \text { (DL) }\end{array}$ & $8,731.6$ & $11,977.8$ & 16.1 & $44,241.5$ & $\begin{array}{l}\text { GSM + UMTS } \\
900(\mathrm{DL})\end{array}$ & 774.9 & 590.9 & 18.7 & $5,561.5$ \\
\hline GSM 1800 (UL) & 0.0 & 0.0 & 0.0 & 1.8 & GSM 1800 (UL) & 0.0 & 0.0 & 0.0 & 0.3 \\
\hline GSM 1800 (DL) & 584.3 & 409.7 & 0.7 & $6,193.1$ & GSM 1800 (DL) & 29.4 & 18.3 & 1.2 & 243.5 \\
\hline DECT & 212.9 & 137.9 & 0.0 & $4,124.7$ & DECT & 8.1 & 4.0 & 0.0 & 167.1 \\
\hline UMTS 2100 (UL) & 0.0 & 0.0 & 0.0 & 5.6 & UMTS 2100 (UL) & 0.0 & 0.0 & 0.0 & 0.1 \\
\hline UMTS 2100 (DL) & $1,421.6$ & $1,270.2$ & 1.1 & $18,445.0$ & UMTS 2100 (DL) & 808.5 & 706.2 & 2.9 & $3,806.9$ \\
\hline WIFI 2G & 0.0 & 0.0 & 0.0 & 7.2 & WIFI 2G & 0.0 & 0.0 & 0.0 & 0.5 \\
\hline LTE 2600 (UL) & 0.4 & 0.0 & 0.0 & 95.8 & LTE 2600 (UL) & 24.5 & 15.7 & 0.0 & 904.7 \\
\hline LTE 2600 (DL) & $12,638.7$ & $8,394.8$ & 1.1 & $95,522.5$ & LTE 2600 (DL) & 557.1 & 420.2 & 1.4 & $7,584.8$ \\
\hline WIMax & 0.0 & 0.0 & 0.0 & 0.8 & WIMax & 0.0 & 0.0 & 0.0 & 0.0 \\
\hline WIFI 5G & 0.0 & 0.0 & 0.0 & 1.8 & WIFI 5G & 0.0 & 0.0 & 0.0 & 0.5 \\
\hline Total & $24,885.9$ & $22,256.1$ & 72.0 & $112,317.7$ & Total & $2,531.0$ & $2,270.5$ & 79.1 & $11,802.6$ \\
\hline $\begin{array}{l}\text { Total excluding } \\
\text { down link }\end{array}$ & 229.6 & 146.5 & 0.0 & $4,155.6$ & $\begin{array}{l}\text { Total excluding } \\
\text { down link }\end{array}$ & 34.1 & 23.1 & 7.2 & $1,069.8$ \\
\hline
\end{tabular}

Levels of RF-radiation at the balcony outside the living room based on measurements in June 5, 6 and August 21, 22, 30, 31, 2017 (apartment at Östermalm, Stockholm). Analysis of all data $\left(\mu \mathrm{W} / \mathrm{m}^{2}\right)$ treating values at detection limit as 0 . In total 5,251 entries corresponding to almost $6 \mathrm{~h}$ of measurements. FM, frequency modulation; TV, television; LTE, long-term evolution; DL, downlink (transmission from base station to mobile phone); UL, uplink (transmission from mobile phone to base station); GSM, global system for mobile communications; UMTS, universal mobile telecommunications system; DECT, digital European cordless telecommunications; WiMAX, worldwide interoperability for microwave access.

Vermeeren et al (20) measured levels using exposimeters EME-Spy 121 and 140 in schools, kindergartens, offices and homes in Belgium and Greece. In homes, the total average was $0.32 \mathrm{~V} / \mathrm{m}\left(272 \mu \mathrm{W} / \mathrm{m}^{2}\right)$ in Belgium and $0.42 \mathrm{~V} / \mathrm{m}\left(468 \mu \mathrm{W} / \mathrm{m}^{2}\right)$ in Greece. The maximum levels were $0.77 \mathrm{~V} / \mathrm{m}\left(1,574 \mu \mathrm{W} / \mathrm{m}^{2}\right)$ in Belgium and $2.08 \mathrm{~V} / \mathrm{m}\left(11,482 \mu \mathrm{W} / \mathrm{m}^{2}\right)$ in Greece. In Belgium, FM-radio, GSM 900 down link from bases stations, and DECT telephones contributed most of the radiation, and in Greece DECT and Wi-Fi $2.45 \mathrm{GHz}$ contributed most.

Verlock et al (21) measured schools, homes and public places in Belgium with a Narda NBM-550 in the frequency range $100 \mathrm{kHz}-6 \mathrm{GHz}$. Total means for the measurements was $0.45 \mathrm{~V} / \mathrm{m}\left(537 \mu \mathrm{W} / \mathrm{m}^{2}\right)$, for homes $0.08 \mathrm{~V} / \mathrm{m}\left(16.9 \mu \mathrm{W} / \mathrm{m}^{2}\right)$, and maximum value in homes was $1.08 \mathrm{~V} / \mathrm{m}\left(3,096 \mu \mathrm{W} / \mathrm{m}^{2}\right)$.
Table VI. Levels of RF-radiation in the girls's bedroom (Östermalm, Stockholm).

Levels of RF-radiation in the girls's bedroom based on measurements in June 5, 6 and August 21, 22, 30, 31, 2017 (apartment at Östermalm, Stockholm). Analysis of all data $\left(\mu \mathrm{W} / \mathrm{m}^{2}\right)$ treating values at detection limit as 0 . In total 11,440 entries corresponding to almost $13 \mathrm{~h}$ of measurements. FM, frequency modulation; TV, television; LTE, long-term evolution; DL, downlink (transmission from base station to mobile phone); UL, uplink (transmission from mobile phone to base station); GSM, global system for mobile communications; UMTS, universal mobile telecommunications system; DECT, digital European cordless telecommunications; WiMAX, worldwide interoperability for microwave access.

These studies, published from 2009 to 2017, show a large variation in the levels of RF radiation, with highest levels measured in Stockholm.

One obstacle to those concerned with RF radiation exposure in Sweden, as in many other countries, is that different authorities base their guideline for exposure on the International Commission on Non-Ionizing Radiation Protection (ICNIRP). This guideline is based on short-term (acute) exposure. Chronic, low-intensity cumulative exposures, possible long term health effects, and non-thermal biological effects have been ignored. The ICNIRP safety limit established in 1998 (22) was updated in 2009 (23) without change. The guideline from the ICNIRP for RF radiation is 2 to $10 \mathrm{~W} / \mathrm{m}^{2}\left(2,000,000\right.$ to $\left.10,000,000 \mu \mathrm{W} / \mathrm{m}^{2}\right)$ depending 
Table VII. Levels of RF-radiation in the boy's bedroom (Östermalm, Stockholm).

\begin{tabular}{|c|c|c|c|c|}
\hline Variable & Mean & Median & Min & Max \\
\hline FM & 0.5 & 0.4 & 0.0 & 407.6 \\
\hline TV3 & 0.0 & 0.0 & 0.0 & 6.1 \\
\hline TETRA I & 0.0 & 0.0 & 0.0 & 16.6 \\
\hline TETRA II & 0.0 & 0.0 & 0.0 & 1.2 \\
\hline TETRA III & 0.0 & 0.0 & 0.0 & 0.6 \\
\hline TV4\&5 & 2.2 & 0.0 & 0.0 & 304.8 \\
\hline LTE 800 (DL) & 448.2 & 292.4 & 2.4 & $8,651.6$ \\
\hline LTE 800 (UL) & 0.0 & 0.0 & 0.0 & 0.0 \\
\hline $\begin{array}{l}\text { GSM + UMTS } \\
900 \text { (UL) }\end{array}$ & 0.0 & 0.0 & 0.0 & 0.2 \\
\hline $\begin{array}{l}\text { GSM + UMTS } \\
900 \text { (DL) }\end{array}$ & 756.1 & 558.8 & 6.4 & $7,056.1$ \\
\hline GSM 1800 (UL) & 0.0 & 0.0 & 0.0 & 0.1 \\
\hline GSM 1800 (DL) & 29.4 & 18.7 & 0.7 & 474.6 \\
\hline DECT & 10.5 & 5.9 & 0.0 & 353.4 \\
\hline UMTS 2100 (UL) & 0.0 & 0.0 & 0.0 & 0.1 \\
\hline UMTS 2100 (DL) & 124.3 & 114.8 & 1.5 & $1,158.9$ \\
\hline WIFI 2G & 0.0 & 0.0 & 0.0 & 1.2 \\
\hline LTE 2600 (UL) & 0.2 & 0.1 & 0.0 & 14.1 \\
\hline LTE 2600 (DL) & 99.7 & 57.3 & 0.5 & $1,352.2$ \\
\hline WIMax & 0.0 & 0.0 & 0.0 & 0.0 \\
\hline WIFI 5G & 0.0 & 0.0 & 0.0 & 0.9 \\
\hline Total & $1,471.1$ & $1,122.3$ & 58.5 & $13,739.1$ \\
\hline $\begin{array}{l}\text { Total excluding } \\
\text { down link }\end{array}$ & 13.4 & 6.8 & 0.0 & 427.8 \\
\hline
\end{tabular}

Levels of RF-radiation in the boy's bedroom based on measurements in June 5, 6 and August 21, 22, 30, 31, 2017 (apartment at Östermalm, Stockholm). Analysis of all data $\left(\mu \mathrm{W} / \mathrm{m}^{2}\right)$ treating values at detection limit as 0 . In total 14,161 entries corresponding to almost $16 \mathrm{~h}$ of measurements. FM, frequency modulation; TV, television; LTE, long-term evolution; DL, downlink (transmission from base station to mobile phone); UL, uplink (transmission from mobile phone to base station); GSM, global system for mobile communications; UMTS, universal mobile telecommunications system; DECT, digital European cordless telecommunications; WiMAX, worldwide interoperability for microwave access.

on frequency (22). The Swedish Radiation Safety Authority (SSM) has adopted the ICNIRP guideline. Many experts at the SSM panel are also members of ICNIRP, which suggests a conflict of interest, since they would rarely compromise the ICNIRP view by expressing critical opinions (15).

Our results on RF radiation exposure in Östermalm are orders of magnitude lower than the ICNIRP guideline, with the median level of exposure being $~ 10,000$ times lower. Using the ICNIRP guideline gives a 'green card' to roll out the technology, and position mobile phone base stations on roofs on apartment houses, in close to those living in the surrounding houses, since the high exposure level by ICNIRP is rarely compromised.

In contrast to ICNIRP, the BioInitiative Reports from 2007 and updated in 2012, based the evaluation on non-thermal
Table VIII. Levels of RF-radiation in the tower bedroom (Östermalm, Stockholm).

\begin{tabular}{|c|c|c|c|c|}
\hline Variable & Mean & Median & Min & $\operatorname{Max}$ \\
\hline FM & 155.0 & 127.2 & 4.0 & $3,441.2$ \\
\hline TV3 & 6.2 & 4.9 & 0.0 & 193.4 \\
\hline TETRA I & 9.1 & 0.0 & 0.0 & 59.7 \\
\hline TETRA II & 1.6 & 1.8 & 0.0 & 33.9 \\
\hline TETRA III & 0.6 & 0.0 & 0.0 & 11.9 \\
\hline TV4\&5 & 14.0 & 0.0 & 0.0 & $2,206.2$ \\
\hline LTE 800 (DL) & $3,712.1$ & $2,333.8$ & 8.6 & $48,136.9$ \\
\hline LTE 800 (UL) & 0.0 & 0.0 & 0.0 & 0.1 \\
\hline $\begin{array}{l}\text { GSM + UMTS } \\
900 \text { (UL) }\end{array}$ & 0.0 & 0.0 & 0.0 & 4.5 \\
\hline $\begin{array}{l}\text { GSM + UMTS } \\
900 \text { (DL) }\end{array}$ & $1,785.4$ & $1,689.1$ & 13.8 & $11,775.7$ \\
\hline GSM 1800 (UL) & 0.0 & 0.0 & 0.0 & 0.1 \\
\hline GSM 1800 (DL) & 59.0 & 47.6 & 0.9 & 657.8 \\
\hline DECT & 18.8 & 13.8 & 0.0 & 593.4 \\
\hline UMTS 2100 (UL) & 0.0 & 0.0 & 0.0 & 0.7 \\
\hline UMTS 2100 (DL) & 77.7 & 65.4 & 1.0 & 495.0 \\
\hline WIFI $2 \mathrm{G}$ & 0.0 & 0.0 & 0.0 & 0.7 \\
\hline LTE 2600 (UL) & 0.0 & 0.0 & 0.0 & 6.4 \\
\hline LTE 2600 (DL) & 114.8 & 75.8 & 2.7 & $3,321.4$ \\
\hline WIMax & 0.0 & 0.0 & 0.0 & 0.0 \\
\hline WIFI 5G & 0.0 & 0.0 & 0.0 & 1.5 \\
\hline Total & $5,954.3$ & $4,503.5$ & 96.8 & $50,431.0$ \\
\hline $\begin{array}{l}\text { Total excluding } \\
\text { down link }\end{array}$ & 205.4 & 158.4 & 13.5 & $3,457.8$ \\
\hline
\end{tabular}

Levels of RF-radiation in the tower bedroom based on measurements in June 5, 6 and August 21, 22, 30, 31, 2017 (apartment at Östermalm, Stockholm). Analysis of all data $\left(\mu \mathrm{W} / \mathrm{m}^{2}\right)$ treating values at detection limit as 0 . In total 6,797 entries corresponding to almost $7.5 \mathrm{~h}$ of measurements. FM, frequency modulation; TV, television; LTE, long-term evolution; DL, downlink (transmission from base station to mobile phone); UL, uplink (transmission from mobile phone to base station); GSM, global system for mobile communications; UMTS, universal mobile telecommunications system; DECT, digital European cordless telecommunications; WiMAX, worldwide interoperability for microwave access.

health effects of RF radiation $(24,25)$. A summary of the BioInitiative Report (2007) was published in a peer-reviewed article (26). Furthermore in both reports, all chapters were based on peer-review published articles, many of them by the authors of the different chapters. Thus, it is incorrect to suggest that the reports represent views and results that are not supported by the scientific literature.

The BioInitiative Report (2012) with updated references defined the scientific benchmark for possible health risks as 30-60 $\mu \mathrm{W} / \mathrm{m}^{2}$. Considering also chronic exposure and the sensitivity of children, the precautionary target level was proposed at $1 / 10$ th of this, i.e., 3-6 $\mu \mathrm{W} / \mathrm{m}^{2}(25)$. This exposure target level has not been acknowledged by SSM in Sweden, thus making it possible to neglect results on exposure, such as 


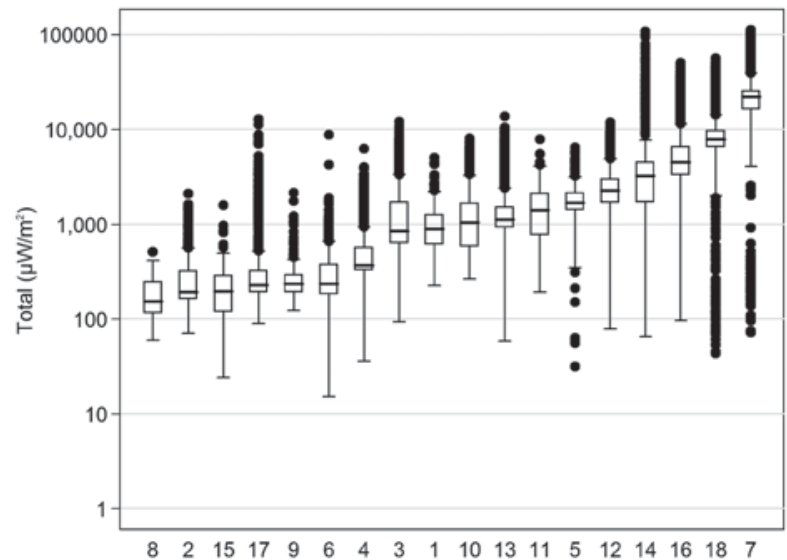

Figure 1. Box plot of exposure in $\mu \mathrm{W} / \mathrm{m}^{2}$, logarithmic scale, for the 6 measurement rounds and total exposure (apartment in Östermalm, Stockholm). The median is indicated by a black line inside each box; the bottom and top of the boxes show first and third quartiles; the end of the whiskers are calculated as $1.5 \mathrm{xIQR}$ (interquartile range). Points represent outliers. Results are displayed according to increasing median level. 1, Balcony outside kitchen; 2, Kitchen; 3, Dining room; 4, Master bedroom; 5, Balcony outside bathroom; 6, Living room; 7, Balcony outside living room; 8, Main hall; 9, Workroom close to kitchen; 10, Workroom close to laundry; 11, Laundry; 12, Girl's bedroom; 13, Boy's bedroom; 14, Balcony outside boy's bedroom; 15, Hall outside elevator; 16, Bedroom in tower; 17, Conference room in tower; 18 , Balcony outside tower.

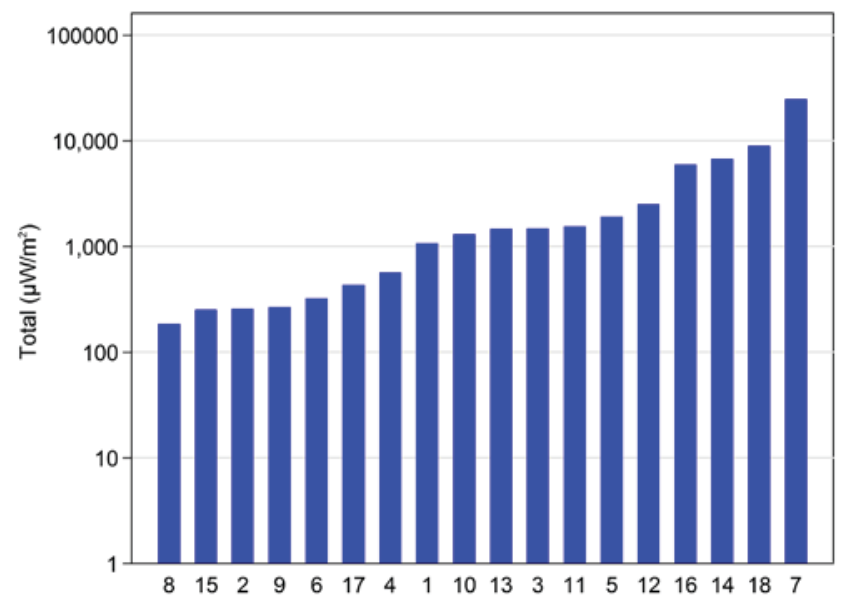

Figure 2. Bar graph on mean levels of total exposure in $\mu \mathrm{W} / \mathrm{m}^{2}$ displayed with a logarithmic scale and ranked according to increasing mean level in the different locations (apartment in Östermalm, Stockholm). 1, Balcony outside kitchen; 2, Kitchen; 3, Dining room; 4, Master bedroom; 5, Balcony outside bathroom; 6 , Living room; 7, Balcony outside living room; 8 , Main hall; 9, Workroom close to kitchen; 10, Workroom close to laundry; 11 , Laundry; 12, Girl's bedroom; 13, Boy's bedroom; 14, Balcony outside boy's bedroom; 15, Hall outside elevator; 16, Bedroom in tower; 17, Conference room in tower; 18 , Balcony outside tower.

in the apartment we measured, and not in providing precaution for the potential detrimental effects on health for those living therein.

We used the same exposimeter in the Geneva WHO building on March 3, 2017. The results show a low mean total exposure level of $21.5 \mu \mathrm{W} / \mathrm{m}^{2}$, median $13.3 \mu \mathrm{W} / \mathrm{m}^{2}$ (range $\min 4.8, \max 433 \mu \mathrm{W} / \mathrm{m}^{2}$ ), i.e., a mean level below the scientific benchmark of $30-60 \mu \mathrm{W} / \mathrm{m}^{2}$ that has been proposed as the 'lowest observed effect level' (LOEL) for RF radiation,

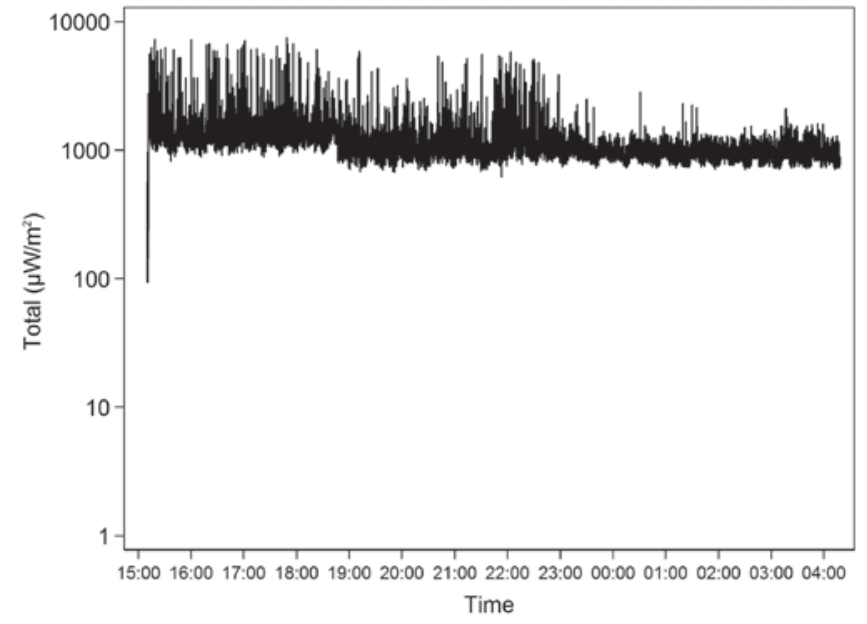

Figure 3. Time variation of measurements in boy's bedroom (apartment in Östermalm, Stockholm) from the afternoon until early next morning $\left(\mu \mathrm{W} / \mathrm{m}^{2}\right.$ on a logarithmic scale). The spikes represent measurements taken every 4th sec.

[see Chapter 24 in the BioInitiative Report (25)]. The major sources were GSM + UMTS 900 DL (3G), GSM 1800 DL (2G) and UMTS 2100 DL (3G), i.e., down link (DL) of RF radiation from base stations. Thus these results indicate that, whether known or unknown, the WHO staff seems to protect themselves from high involuntary RF radiation levels at least within the measured areas of the Geneva building (15).

In the present study, for the whole apartment including the balconies, the measurements of RF radiation had a total mean of $3,811 \mu \mathrm{W} / \mathrm{m}^{2}$ and a total median of $1,313 \mu \mathrm{W} / \mathrm{m}^{2}$. For rooms inside the apartment, the tower bedroom had the highest mean $\left(5,954 \mu \mathrm{W} / \mathrm{m}^{2}\right)$ and median $\left(4,504 \mu \mathrm{W} / \mathrm{m}^{2}\right)$. Also the girl's bedroom with mean $2,531 \mu \mathrm{W} / \mathrm{m}^{2}$ and median $2,271 \mu \mathrm{W} / \mathrm{m}^{2}$ and the boy's bedroom with a mean of $1,471 \mu \mathrm{W} / \mathrm{m}^{2}$ and median $1,122 \mu \mathrm{W} / \mathrm{m}^{2}$ were high values. Time spent in a bedroom is usually many hours per night, which means long term exposure when relatively high levels of $\mathrm{RF}$ radiation are still present.

$\mathrm{RF}$ radiation exposure at or below these levels indicated above have influenced several physiological parameters in the body of mammals in laboratory studies. Effects on oxidative cell stress and DNA damage in cells, opening of the blood-brain barrier, up or down regulated proteins and microRNA in the brain, and testicular dysfunction, have been found. For people living near mobile phone base stations, effects have been seen on neurotransmitters, peripheral blood lymphocytes with DNA damage, lower antioxidant levels, decreased salivary secretion, adverse neuro-behavioral symptoms, and an increased incidence of cancer. People residing near mobile phone base stations have more often complained of sleep disturbances, headaches, dizziness, irritability, concentration difficulties and hypertension. Exposures to RF radiation were all below the reference levels in the ICNIRP guidelines. The effects were caused by non-thermal RF radiation exposure and will now be briefly discussed.

In rats exposed to $\mathrm{RF}$ radiation, the blood brain barrier (BBB) has opened up, leading to leakage into the brain tissues of large molecules, e.g., albumin and toxins that can 
Table IX. Levels of RF-radiation in total for different locations in the apartment (Gärdet, Stockholm).

\begin{tabular}{lrrrrr}
\hline Location & No. & Mean & Median & Min & Max \\
\hline Kitchen & 6,815 & 9.2 & 7.8 & 4.2 & 55.6 \\
Dining room & 5,970 & 16.2 & 15.4 & 6.2 & 60.6 \\
Bedroom & 8,163 & 10.7 & 8.6 & 3.9 & 58.2 \\
Living room & 8,229 & 18.4 & 17.0 & 7.5 & 97.8 \\
Hall & 5,809 & 4.2 & 3.9 & 2.2 & 20.6 \\
Balcony & 1,813 & 82.4 & 73.1 & 9.1 & 195.1 \\
Whole apartment & 36,799 & 15.6 & 12.8 & 2.2 & 195.1 \\
Whole apartment- & 36,799 & 1.1 & 0.7 & 0.0 & 124.6 \\
excluding down link & & & & & \\
\hline
\end{tabular}

Levels of RF-radiation in total for different locations in the apartment based on measurements in October 27-29 and November 6, 2017 (Gärdet, Stockholm). Analysis of all data $\left(\mu \mathrm{W} / \mathrm{m}^{2}\right)$ treating values at detection limit as 0 . Numbers of entries are given for the different locations.

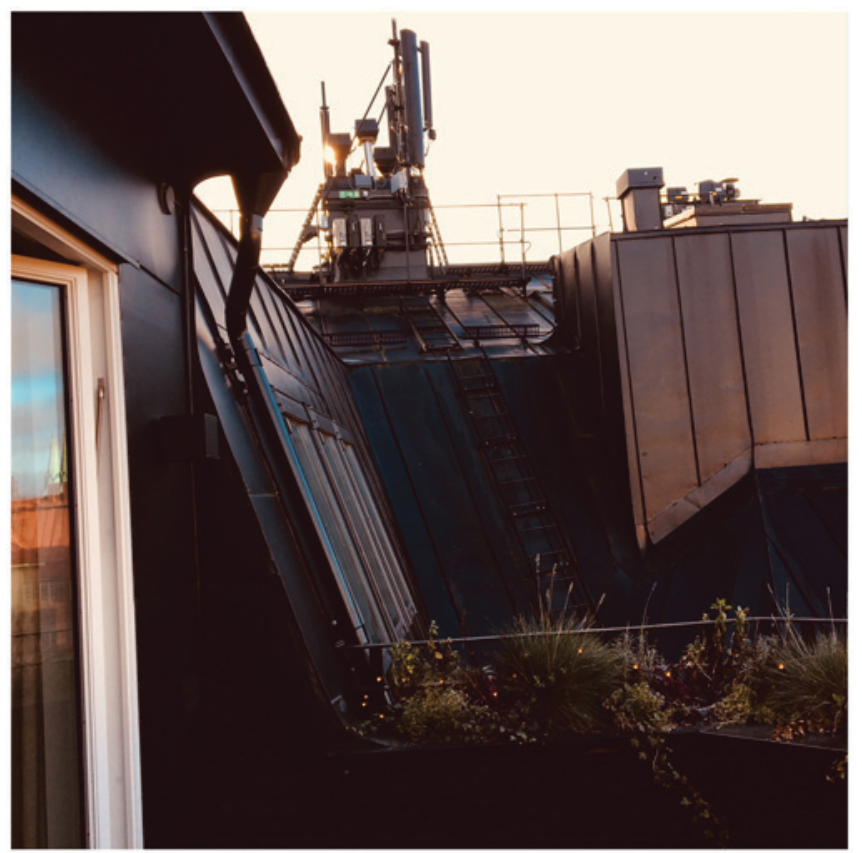

Figure 4. Image taken from the balcony outside the living room where the highest mean and median were measured $\left(24,885.9\right.$ and $\left.22,256.1 \mu \mathrm{W} / \mathrm{m}^{2}\right)$. One group of base stations is located only $12 \mathrm{~m}$ from the balcony.

damage the brain tissue. The BBB is supposed to protect and prevent pathological leakage of toxins from the blood vessels (27). Several studies have shown that the BBB can open after RF radiation from a GSM mobile phone with a peak power output of only $1,000 \mu \mathrm{W}$, and with an average whole body specific energy absorption rate (SAR) of down to $120 \mu \mathrm{W} / \mathrm{kg}$ (28). Stronger effects on health due to RF radiation at lower exposure levels than at higher exposure indicate a U-shaped response curve $(28,29)$.

Difference between sexes exposed to different RF radiation frequencies has been reported, where only female rats showed increased BBB permeability at $900 \mathrm{MHz}$ frequency, whereas male rats had increased $\mathrm{BBB}$ permeability at both GSM 900 and $1,800 \mathrm{MHz}$ pulse-modulated RF radiation (30).

Exposure to $900 \mathrm{MHz}$ for $3 \mathrm{~h}$ per day for 28 days caused extravasation of albumin in the hippocampus and cortex, and impaired spatial memory in rats. The hippocampus, a center for co-ordination of memory and learning in the brain, seems in particular to be a primary target for neuronal damage from RF radiation and opening of the BBB (31). Exposure for $2 \mathrm{~h}$ each week for 55 weeks impaired the memory in rats exposed to GSM $900 \mathrm{MHz}$, but histopathological parameters did not seem to be statistically significantly affected $(32,33)$.

Higher sensitivity to RF radiation has been reported in growing organisms. An increase in protein synthesis in proliferating human cells has been seen after $8 \mathrm{~h}$ of RF radiation exposure, but not in quiescent white blood cells (34). In stems cells, the capacity to repair DNA double-strand breaks was more affected by RF radiation compared to differentiated cells (fibroblasts) (35).

Mice exposed to RF radiation from a GSM $900 \mathrm{MHz}$ mobile phone for $3 \mathrm{~h} /$ day or to DECT base station for $8 \mathrm{~h} /$ day over 8 months showed an up or down regulation of 143 out of 432 proteins analyzed from the cerebellum, hippocampus and frontal lobes of the brain. Several proteins involved in the brain metabolism and different neural functions were altered (36).

Two long-term studies have exposed rats for $24 \mathrm{~h}$ a day for 12 months to RF radiation emitted from a Wi-Fi system at $2.4 \mathrm{GHz}$. The peak power was $100,000 \mu \mathrm{W}$, with the antenna $50 \mathrm{~cm}$ above the cage. The SAR value over $10 \mathrm{~g}$ of brain tissue was $1,030 \mu \mathrm{W} / \mathrm{kg}$. One study examined 5 different microRNAs (miRNA) in the rat brains, 2 of which decreased at least $70 \%$. miRNA is important in the proliferation, differentiation, function and maintenance of all cells, including neurons; and dysfunction of their pathways can contribute to pathogenesis of neurodegenerative disorders, as well as being a key indicator of epigenetic changes and cancer risk (37).

Rat testes and prostate were examined in another study, where the SAR value was $1,020 \mathrm{~W} / \mathrm{kg}$ over 10 gram tissue. The Wi-Fi exposed rats showed statistically significant greater effects on testicular function and histology, and increased defects in the heads of sperms (38). DNA damage in sperms has been reported in several other Wi-Fi exposure investigations (39-41).

In a review of 100 studies, Yakymenko et al (42) showed oxidative effects of low-intensity RF radiation on living cells, with exposure down to $2,500 \mu \mathrm{W} / \mathrm{m}^{2}$ (43). SAR values down to $600 \mu \mathrm{W} / \mathrm{kg}$ increased oxidative stress in the cells $(44,45)$. Embryos of Japanese quails were exposed to RF radiation using GSM $900 \mathrm{MHz}$ (46). The average intensity of RF radiation on the surface of hatching eggs was $2,500 \mu \mathrm{W} / \mathrm{m}^{2}\left(0.25 \mu \mathrm{W} / \mathrm{cm}^{2}\right)$. SAR was calculated to be $3 \mu \mathrm{W} / \mathrm{kg}$. A statistically significant overproduction of reactive oxygen species (ROS) and oxidative damage of DNA in living cells was reported compared with the control group given no exposure. The exposure was far below the guideline of the ICNIRP for RF radiation at 2 to $10 \mathrm{~W} / \mathrm{m}^{2}$ depending on frequency and $2 \mathrm{~W} / \mathrm{kg}$ to the brain. The results showed that the ICNIRP guidelines are outdated. Moreover, using a safety factor of 10 would give $250 \mu \mathrm{W} / \mathrm{m}^{2}$ as a guideline, a level easily exceeded in many places, e.g., our measurements taken at the Stockholm Central Railway 
Station (13), in the Old Town (14) and in most rooms in the present apartment at Östermalm.

Long-term RF radiation exposure for $2 \mathrm{~h}$ per day 5 days per week for 30-180 days at SAR values of 595-667 $\mu \mathrm{W} / \mathrm{kg}$ and at the frequencies $900,1,800$ and 2,450 $\mathrm{MHz}$ resulted in oxidative stress, increase in pro-inflammatory cytokines, DNA damage with single-strand breaks, reduced levels of neurotransmitters and downregulation of mRNA in the hippocampus in the brain of rats $(45,47,48)$, with memory and learning also being affected (47). More deleterious effects on several of the parameters were seen with an increase in frequency; $1,800 \mathrm{MHz}$ and $2,450 \mathrm{MHz}$ had a statistically significant effect, not only compared with sham exposed animals, but in some cases compared with $900 \mathrm{MHz}$ exposure.

Even a SAR value down to $85 \mu \mathrm{W} / \mathrm{kg}$ exposure from $900 \mathrm{MHz}$ during $2 \mathrm{~h}$ /day, 5 days/week for 30 days, increased oxidative stress parameters in lipid peroxidation and protein oxidation, and resulted in a statistically significant impairment in spatial memory in rats (49).

The pancreas was examined in young rats of 6 weeks of age exposed for $3 \mathrm{~h} /$ day for 30 days to $2.45 \mathrm{MHz}$, pulsed $217 \mathrm{~Hz}$, from a RF test generator, with similar exposure to Wi-Fi $2.45 \mathrm{GHz}$. Compared to the control group, these rats had statistically significant increased levels of glucose, lipase and amylase in the blood, degenerative changes in both endocrine and exocrine cells, increased inflammatory cells and immune-positive markers, especially in the islets of Langerhans. These findings point to a deleterious effect on both endocrine and exocrine functioning of the pancreas. Langerhans islets secret hormones like insulin, glucagon and somatostatin, which regulate blood glucose levels; insufficient secretion can lead to diabetes, which have seen a big increase during the last few decades in parallel with the fast increasing use of wireless techniques (50).

The National Toxicology Program (NTP) under the National Institutes of Health (NIH) in the USA released a report in 2016 which showed an increased incidence of glioma in the brain and malignant schwannoma in the heart in up to 2 years in RF irradiated rats. These findings support human epidemiological studies on brain tumor risk and strengthen the association between RF radiation and cancer (51). Recent results from the NTP study showed genotoxicity of RF radiation in rats and mice (52). This result supports several previous findings of DNA strand-breaks in rat brain cells exposed to RF radiation, as first published by Lai and Singh (53). RF radiation leads to oxidative stress in biological systems, including the brain, due to an increase in free radicals and changes in antioxidant defence systems.

The NTP study has greatly strengthened the evidence of cancer risk, and reaffirms that there is sufficient scientific evidence to reclassify wireless phone radiation as a carcinogenic agent in Group 1, according to the IARC classification. It confirms that the current public safety limits based only on the thermal effects are inadequate and do not protect us against the associated detrimental health effects $(10,11)$.

In the village of Rimbach in Germany, a GSM mobile base station was built in 2004. Buchner and Eger (54) studied 60 inhabitants (aged 0-69 years), measuring the neurotransmitters adrenaline, noradrenaline, dopamine and phenyletylamine (PEA) in second morning urine samples before the base station was activated, and at 6,12 and 18 months after activation. RF radiation was measured in peak value of the power density after the activation of the base station outside each participant's houses. The participants were divided into 3 groups based on exposure: less than $60,60-100$ or $>100 \mu \mathrm{W} / \mathrm{m}^{2}$. The stress hormones adrenaline and noradrenaline were significantly increased over the first 6 months after the activation of the GSM base station. The levels decreased, but were not restored to initial level, after 18 months. This was especially evident in the children and the chronically ill adults. A statistically significant decrease was seen for dopamine levels over the first 6 months, after which dopamine levels increased, but did not return to their initial level. For the participants with RF radiation exposure over $100 \mu \mathrm{W} / \mathrm{m}^{2}$ at home, the 3 neurotransmitters showed a clear dose-response relationship. PEA levels decreased first for the highest exposed group, but after 18 months the 3 groups were all statistically significantly decreased. DECT, Wi-Fi and other wireless devices at home seemed to amplify the effect of GSM radiation. After 18 months, even the lowest exposed group (RF radiation $<60 \mu \mathrm{W} / \mathrm{m}^{2}$ ) had decreased dopamine and PEA levels.

PEA is often low in patients with depression, and in adults and children with attention deficit hyperactivity disorder (ADHD). Chronic dysregulation of the catecholamine system and PEA may contribute to chronic illnesses and health problems in the long term. Several of the 60 participants had new symptoms, including headache, dizziness, concentration problems, sleep disturbances and allergies (54).

Khurana et al (55) reviewed epidemiological studies on populations living near mobile phone base stations for indications of any health risks for humans. In $80 \%$ of the studies, people living $<500 \mathrm{~m}$ from base stations had an increased prevalence in particular of adverse neuro-behavioral symptoms and cancer. In another review of 56 studies, Levitt and Lai (56) found that exposure from base stations and other antenna arrays induced changes in immunological and reproductive systems, DNA double-strand breaks, influence on calcium movement in the heart, and increased proliferation of astrocytoma cancer cells in humans and laboratory animals. Cortisol and thyroid hormones were also affected in people living near base stations $(57,58)$.

A study with 40 healthy persons in India living $<80 \mathrm{~m}$ from a mobile phone base station showed that RF radiation definitely induced DNA damage, a lowering of antioxidants levels, and a higher frequency of micronuclei in peripheral blood lymphocytes compared with a control group living $>300 \mathrm{~m}$ from the base station. Those exposed were between 20 and 40 years old, 18 being male and 22 female. All but 3 used a mobile phone every day. None of the participants had occupational exposure to RF radiation and none lived near a high tension electric power line or electric transformer station (59).

Sleep disturbances, burned-out syndromes, depressions, pain problems and sick leaves are being increasingly reported in our daily papers. Scientific studies on humans, animals and biological material show adverse effects on physiological parameters due to RF radiation. The complex picture relates to wellbeing within the stress of working life and at home, and the rapid technological development leading to more sedentary behavior, with both children and adults watching the screen of a smart phone, laptop or television for many hours each day. 
RF radiation may contribute to deterioration in physical and mental wellbeing and health. There seems also to be a large difference in sensitivity to RF radiation between individuals, both in humans and animals $(28,60)$. One example is the findings of downregulation of a sleep-inducing neurohormone in the age group of 18-30 years. Its level decreased with increasing number of years in use of a wireless phone (61), whereas no effect was seen among older persons (62). Since tumors take several decades to develop, and chronic illnesses, like neurological and cardiac diseases, come in older ages, we will only know in the future if and to what degree RF radiation may influence on the incidence of these illnesses and disorders.

Children are probably more sensitive to $\mathrm{RF}$ radiation because of their growing bodies and more immature cells, and also because they will be exposed for probably a whole lifetime in contrast to present generation $(34,35,63)$. High mean exposure levels in the bedrooms of growing children (one at 2,531 $\mu \mathrm{W} / \mathrm{m}^{2}$ and the other at $1,471 \mu \mathrm{W} / \mathrm{m}^{2}$ ) may have deleterious effects on their physical and mental health, based on data already obtained from humans and animals. Cognitive effects have also been found in such studies $(17,32,48,49)$, which might affect a child's future work and memory function in older age.

This study shows high RF radiation levels in an apartment with 2 groups of base stations in the near vicinity. Of special concern is the levels in bedrooms, especially those two used by children, since they seem to be more vulnerable to adverse health effects than grown-ups. They have also a longer expected life in which illnesses may later become manifest. The results indicate that this apartment is unsuitable for long-term living based on current knowledge of the potential adverse effects on health of RF radiation. For definitive conclusions regarding the effects of RF radiation levels from the base stations, one option would be to turn off all nearby base stations and make new measurements; some exposure from more distant located base stations cannot be excluded. However, the present results show that the safest solution is to turn off permanently and dismantle the base stations.

\section{Acknowledgements}

Not applicable.

\section{Funding}

The study was supported by grants from Mr Brian Stein, Cancer och Allergifonden, Cancerhjälpen, and the Pandora-Foundation for Independent Research, Berlin, Germany.

\section{Availability of data and materials}

The datasets generated and analyzed during the current study are not publicly available due to measurements performed in a private apartment, but are available from the corresponding author on reasonable request.

\section{Authors' contributions}

LHa made all measurements and drafted the article. MC made all statistical analyses, tables and figures. LHe was responsible for the literature review of other measurement studies in homes and studies about the biological effects from non-thermal levels of RF radiation. All authors contributed to the final article and approved the submitted version.

\section{Ethics approval and consent to participate}

Not applicable.

\section{Consent for publication}

Not applicable.

\section{Competing interests}

The authors declare that they have no competing interests.

\section{References}

1. Cardis E, Deltour I, Mann S, Moissonnier M, Taki M, Varsier N, Wake K and Wiart J: Distribution of RF energy emitted by mobile phones in anatomical structures of the brain. Phys Med Biol 53: 2771-2783, 2008

2. Gandhi OP, Morgan LL, de Salles AA, Han YY,Herberman RB and Davis DL: Exposure limits: The underestimation of absorbed cell phone radiation, especially in children. Electromagn Biol Med 31: 34-35, 2012.

3. Baan R, Grosse Y, Lauby Secretan B, El Ghissassi F, Bouvard V, Benbrahim-Tallaa L, Guha N, Islami F, Galichet L and Straif K; WHO International Agency for Research on Cancer Monograph Working Group: Carcinogenicity of radiofrequency electromagnetic fields. Lancet Oncol 12: 624-626, 2011.

4. IARC Monographs on the Evaluation of Carcinogenic Risks to Humans, Non-Ionizing Radiation, Part 2: Radiofrequency Electromagnetic Fields, vol. 102. IARC, Lyon, 2013. http://monographs.iarc.fr/ENG/Monographs/vol102/mono102. pdf. Accessed November 9, 2017.

5. Hardell L, Carlberg M and Hansson Mild K: Pooled analysis of case-control studies on malignant brain tumours and the use of mobile and cordless phones including living and deceased subjects. Int J Oncol 38: 1465-1474, 2011.

6. INTERPHONE Study Group: Brain tumour risk in relation to mobile telephone use: Results of the INTERPHONE international case-control study. Int J Epidemiol 39: 675-694, 2010.

7. Hardell L, Carlberg M, Söderqvist F and Hansson Mild K: Pooled analysis of case-control studies on acoustic neuroma diagnosed 1997-2003 and 2007-2009 and use of mobile and cordless phones. Int J Oncol 43: 1036-1044, 2013.

8. Coureau G, Bouvier G, Lebailly P, Fabbro-Peray P, Gruber A, Leffondre K, Guillamo JS, Loiseau H, Mathoulin-Pélissier S, Salamon R and Baldi I: Mobile phone use and brain tumours in the CERENAT case-control study. Occup Environ Med 71: 514-522, 2014

9. Hardell L and Carlberg M: Mobile phone and cordless phone use and the risk for glioma-Analysis of pooled case-control studies in Sweden, 1997-2003 and 2007-2009. Pathophysiology 22: 1-13, 2015.

10. Carlberg $\mathrm{M}$ and Hardell L: Evaluation of mobile phone and cordless phone use and glioma risk using the Bradford Hill viewpoints from 1965 on association or causation. Biomed Res Int 2017: 9218486, 2017.

11. Hardell L and Carlberg M: Using the Hill viewpoints from 1965 for evaluating strengths of evidence of the risk for brain tumors associated with use of mobile and cordless phones. Rev Environ Health 28: 97-106, 2013.

12. Hill AB: The environment and disease: Association or causation? Proc R Soc Med 58: 295-300, 1965.

13. Hardell L, Koppel T, Carlberg M, Ahonen M and Hedendahl L: Radiofrequency radiation at Stockholm central railway station in Sweden and some medical aspects on public exposure to RF fields. Int J Oncol 49: 1315-1324, 2016.

14. Hardell L, Carlberg M, Koppel T and Hedendahl L: High radiofrequency radiation at Stockholm Old Town: An exposimeter study including the Royal Castle, Supreme Court, three major squares and the Swedish Parliament. Mol Clin Oncol 6: 462-476, 2017. 
15. Hardell L: World Health Organization, radiofrequency radiation and health-a hard nut to crack (Review). Int J Oncol 51: 405-413, 2017

16. Estenberg $\mathrm{J}$ and Augustsson T: Extensive frequency selective measurements of radiofrequency fields in outdoor environments performed with a novel mobile monitoring system. Bioelectromagnetics 35: 227-230, 2014.

17. Calvente I, Pérez-Lobato R, Núñez MI, Ramos R, Guxens M, Villalba J, Olea $\mathrm{N}$ and Fernández MF: Does exposure to environmental radiofrequency electromagnetic fields cause cognitive and behavioral effects in 10-year-old boys? Bioelectromagnetics 37: 25-36, 2016.

18. Frei P, Mohler E, Neubauer G, Theis G, Bürgi A, Fröhlich J, Braun-Fahrländer C, Bolte J, Egger $M$ and Röösli $M$ : Temporal and spatial variability of personal exposure to radio frequency electromagnetic fields. Environ Res 109: 779-785, 2009.

19. Roser K, Schoeni A, Struchen B, Zahner M, Eeftens M, Fröhlich J and Röösli M: Personal radiofrequency electromagnetic field exposure measurements in Swiss adolescents. Environ Int 99: 303-314, 2017.

20. Vermeeren G, Markakis I, Goeminne F, Samaras T, Martens L and Joseph W: Spatial and temporal RF electromagnetic field exposure of children and adults in indoor micro environments in Belgium and Greece. Prog Biophys Mol Biol 113: 254-263, 2013

21. Verlock L, Joseph W, Goeminne F, Martens L, Verlack M and Constandt $\mathrm{K}$ : Assessment of radiofrequency exposures in schools, homes, and public places in Belgium. Health Phys 107: 503-513, 2014.

22. International Commission on Non-Ionizing Radiation Protection: Guidelines for limiting exposure to time-varying electric, magnetic, and electromagnetic fields (up to $300 \mathrm{GHz}$ ). Health Phys 74: 494-522, 1998.

23. International Commission on Non-Ionizing Radiation Protection: ICNIRP statement on the 'Guidelines for limiting exposure to time-varying electric, magnetic, and electromagnetic fields (up to $300 \mathrm{GHz}$ )'. Health Phys 97: 257-258, 2009.

24. BioInitiative Working Group: BioInitiative Report 2007 A Rationale for a Biologically-based Public Exposure Standard for Electromagnetic Fields (ELF and RF). Sage C and Carpenter DO (eds). Bioinitiative, 2007. http://www.bioinitiative.org/table-of-contents/. Accessed November 9, 2017.

25. BioInitiative Working Group: BioInitiative Report 2012: A Rationale for Biologically-based Public Exposure Standards for Electromagnetic Radiation. Sage C and Carpenter DO (eds). http://www.bioinitiative.org. Accessed November 9, 2017.

26. Hardell L and Sage C: Biological effects from electromagnetic field exposure and public exposure standards. Biomed Pharmacother 62: 104-109, 2008

27. Salford LG, Brun AE, Eberhardt JL, Malmgren L and Persson BR: Nerve cell damage in mammalian brain after exposure to microwaves from GSM mobile phones. Environ Health Perspect 111: 881-883; Discussion A408, 2003.

28. Nittby H, Brun A, Eberhardt J, Malmgren L, Persson BR and Salford LG: Increased blood-brain barrier permeability in mammalian brain 7 days after exposure to the radiation from a GSM-900 mobile phone. Pathophysiology 16: 103-112, 2009.

29. Eberhardt JL, Persson BR, Brun AE, Salford LG and Malmgren LO: Blood-brain barrier permeability and nerve cell damage in rat brain 14 and 28 days after exposure to microwaves from GSM mobile phones. Electromagn Biol Med 27: 215-229, 2008.

30. Sirav B and Seyhan N: Effects of GSM modulated radio-frequency electromagnetic radiation on permeability of blood-brain barrier in male \& female rats. J Chem Neuroanat 75: 123-127, 2016.

31. Tang J, Zhang Y, Yang L, Chen Q, Tan L, Zuo S, Feng H, Chen $Z$ and Zhu G: Exposure to $900 \mathrm{MHz}$ electromagnetic fields activates the mkp-1/ERK pathway and causes blood-brain barrier damage and cognitive impairment in rats. Brain Res 1601: 92-101, 2015.

32. Nittby H, Grafström G, Tian DP, Malmgren L, Brun A, Persson BR, Salford LG and Eberhardt J: Cognitive impairment in rats after long-term exposure to GSM-900 mobile phone radiation. Bioelectromagnetics 29: 219-232, 2008.
33. Grafström G, Nittby H, Brun A, Malmgren L, Persson BR, Salford LG and Eberhardt J: Histopathological examinations of rat brains after long-term exposure to GSM-900 mobile phone radiation. Brain Res Bull 77: 257-263, 2008.

34. Gerner C, Haudek V, Schandl U, Bayer E, Gundacker N, Hutter HP and Mosgoeller W: Increased protein synthesis by cells exposed to a $1,800-\mathrm{MHz}$ radio-frequency mobile phone electromagnetic field, detected by proteome profiling. Int Arch Occup Environ Health 83: 691-702, 2010.

35. Markovà E, Malmgren LO and Belyaev IY: Microwaves from mobile phones inhibit 53BP1 focus formation in human stem cells stronger than in differentiated cells: Possible mechanistic link to cancer risk. Environ Health Perspect 118: 394-399, 2010.

36. Fragopoulou AF, Samara A, Antonelou MH, Xanthopoulou A, Papadopoulou A, Vougas K, Koutsogiannopoulou E, Anastasiadou E, Stravopodis DJ, Tsangaris GT and Margaritis LH: Brain proteome response following whole body exposure of mice to mobile phone or wireless DECT base radiation. Electromagn Biol Med 31: 250-274, 2012.

37. Dasdag S, Akdag MZ, Erdal ME, Erdal N, Ay OI, Ay ME, Yilmaz SG, Tasdelen B and Yegin K: Effects of $2.4 \mathrm{GHz}$ radiofrequency radiation emitted from Wi-Fi equipment on microRNA expression in brain tissue. Int J Radiat Biol 91: 555-561, 2015.

38. Dasdag S, Tas M, Akdag MZ and Yegin K: Effect of long-term exposure of $2.4 \mathrm{GHz}$ radiofrequency radiation emitted from Wi-Fi equipment on testes functions. Electromagn Biol Med 34: 37-42, 2015.

39. Avendaño C, Mata A, Sanchez Samiento CA and Doncel GF: Use of laptop computers connected to internet through Wi-Fi decreases human sperm motility and increases sperm DNA fragmentation. Fertil Steril 97: 39-45.e2, 2012.

40. Atasoy HI, Gunal MY, Atasoy P, Elgun S and Bugdayci G: Immunohistopathologic demonstration of deleterious effects on growing rat testes of radiofrequency waves emitted from conventional Wi-Fi devices. J Pediatr Urol 9: 223-229, 2013.

41. Akdag MZ, Dasdag S, Canturk F, Karabulut D, Caner Y and Adalier N: Does prolonged radiofrequency radiation emitted from Wi-Fi devices induce DNA damage in various tissues of rats? J Chem Neuroanat 75: 116-122, 2016.

42. Yakymenko I, Tsybulin O, Sidorik E, Henshel D, Kyrylenko O and Kyrylenko S: Oxidative mechanisms of biological activity of low-intensity radiofrequency radiation. Electromagn Biol Med 35: 186-202, 2016.

43. Burlaka A, Tsybulin O, Sidorik E, Lukin S, Polishuk V, Tsehmistrenko S and Yakymenko I: Overproduction of free radical species in embryonal cells exposed to low intensity radiofrequency radiation. Exp Oncol 35: 219-225, 2013.

44. Megha K, Deshmukh PS, Banerjee BD, Tripathi AK and Abegaonkar MP: Microwave radiation induced oxidative stress, cognitive impairment and inflammation in brain of Fischer rats. Indian J Exp Biol 50: 889-896, 2012.

45. Megha K, Deshmukh PS, Banerjee BD, Tripathi AK, Ahmed R and Abegaonkar MP: Low intensity microwave radiation induced oxidative stress, inflammatory response and DNA damage in rat brain. Neurotoxicology 51: 158-165, 2015.

46. Tsybulin O, Sidorik E and Yakymenko I: Oxidative effect of low-intensity microwave radiation in the model of developing quail embryos. Oxid Antioxid Med Sci 6: 9-13, 2017.

47. Megha K, DeshmukhPS, Ravi AK, Tripathi AK, Abegaonkar MP and Banerjee BD: Effect of low-intensity microwave radiation on monoamine neurotransmitters and their key regulating enzymes in rat brain. Cell Biochem Biophys 73: 93-100, 2015.

48. Deshmukh PS, Nasare N, Megha K, Banerjee BD, Ahmed RS, Singh D, Abegaonkar MP, Tripathi AK and Mediratta PK: Cognitive impairment and neurogenotoxic effects in rats exposed to low-intensity microwave radiation. Int J Toxicol 34: 284-290, 2015.

49. Deshmukh PS, Banerjee BD, Abegaonkar MP, Megha K, Ahmed RS, Tripath AK and Mediratta PK: Effect of low level microwave radiation exposure on cognitive function and oxidative stress in rats. Indian J Biochem Biophys 50: 114-119, 2013.

50. Topsakal S, Ozmen O, Cicek E and Comlekci S: The amelioratove effect of gallic acid on pancreas lesions induced by $2,45 \mathrm{GHz}$ electromagnetic radiation (Wi-Fi) in young rats. J Rad Res Appl Sci 10: 233-240, 2017.

51. Wyde M,CestaM,Blystone C,ElmoreS,FosterP,HoothM,KisslingG, Malarkey D, Sills R, Stout M, et al: Report of Partial findings from the National Toxicology Program Carcinogenesis Studies of Cell Phone Radiofrequency Radiation in Hsd: Sprague Dawley® SD rats (Whole Body Exposure). US National Toxicology Program (NTP), 2016. http://biorxiv.org/content/biorxiv/early/2016/05/26/055699. full.pdf. Accessed November 9, 2017. 
52. Smith-Roe SL, Wyde ME, Stout MD, Winters JW, Hobbs CA Shepard KG, Green AS, Kissling GA and Tice RR: Evaluation of the genotoxicity of cell phone radiofrequency radiation in male and female rats and mice following subchronic exposure. In Proceedings of the Environmental Mutagenesis and Genomics Society, 48 ${ }^{\text {th }}$ Annual Meeting, Raleigh, NC, 2017.

53. Lai H and Singh NP: Melatonin and a spin-trap compound block radiofrequency electromagnetic radiation-induced DNA strand breaks in rat brain cells. Bioelectromagnetics 18: 446-454, 1997.

54. Buchner K and Eger $\mathrm{H}$ : Changes of clinically important neurotransmitters under the influence of modulated RF-fields-a long term study under real-life conditions. Umwelt Med Ges 24 44-57, 2011.

55. Khurana VG, Hardell L, Everaert J, Bortkiewicz A, Carlberg M and Ahonen M: Epidemiological evidence for a health risk from mobile phone base stations. Int J Occup Environ Health 16: 263-267, 2010.

56. Levitt BB and Lai H: Biological effects from exposure to electromagnetic radiation emitted by cell tower base stations and other antenna arrays. Environ Rev 18: 369-395, 2010.

57. Augner C, Hacker GW, Oberfeld G, Florian M, Hitzl W, Hutter J and Pauser G: Effects of exposure to GSM mobile phone base station signals on salivary cortisol, alpha-amylase, and immunoglobulin A. Biomed Environ Sci 23: 199-207, 2010.

58. Eskander EF, Estefan SF and Abd-Rabou AA: How does long term exposure to base stations and mobile phones affect human hormone profiles? Clin Biochem 45: 157-161, 2012.

59. Zothansiama, Zosangzuali M, Lalramdinpuii M and Jagetia GC: Impact of radiofrequency radiation on DNA damage and antioxidants in peripheral blood lymphocytes of humans residing in the vicinity of mobile phone base stations. Electromagn Biol Med 36: 295-305, 2017.
60. Hedendahl L, Carlberg M and Hardell L: Electromagnetic hypersensitivity-an increasing challenge to the medical profession. Rev Environ Health 30: 209-215, 2015.

61. Hardell L, Söderqvist F, Carlberg M, Zetterberg H and Mild K: Exposure to wireless phone emissions and serum beta-trace protein. Int J Mol Med 26: 301-306, 2010.

62. Söderqvist F, Carlberg M, Zetterberg H and Hardell L: Use of wireless phones and serum $\beta$-trace protein in randomly recruited persons aged 18-65 years: A cross-sectional study. Electromagn Biol Med 31: 416-424, 2012.

63. Morgan LL, Kesari S and Davis DL: Why children absorb more microwave radiation than adults: The consequences. J Microsc Ultrastruct 2: 197-204, 2014.

This work is licensed under a Creative Commons Attribution-NonCommercial-NoDerivatives 4.0 International (CC BY-NC-ND 4.0) License. 